\title{
The effect of organization restructuring on organization performance viewed from employee performance and leadership effectiveness at maluku provincial education office
}

\author{
Zainuddin Notanubun, Ribka Lemi Ririhena, John Rafafy Batlolona \\ Primary Teacher Education, Faculty of Teachers Training and Education, University of Pattimura, Indonesia
}

\begin{tabular}{l}
\hline \hline Article Info \\
\hline Article history: \\
Received Sep 19, 2018 \\
Revised Oct 29, 2018 \\
Accepted Des 15, 2018
\end{tabular}

\section{Keywords:}

Effectiveness

Organization

Performance

Restructuring

\begin{abstract}
The focus of this research is to comprehensively analyze the effect of organization restructuring on the performance of the organization, directly or indirectly, involving 276 employees in the education office and the Ministry of Education and Culture offices and collected by survey method. Data analysis was done using causal correlation technique to see the effect of organization restructuring on organization performance. The results of the research indicate that there is a direct influence of organization restructuring on organization performance. Another result is that there is an indirect effect of restructuring through employee performance and leadership effectiveness on organization performance. The influence of organization performance improvement is due to, organization restructuring implemented in Maluku Province education office has lead to behavior change, where the employees of education office were able to improve individual performance and can work together with the leadership as an efficient and effective structure. This has an impact on improving organization performance.
\end{abstract}

Copyright $@ 2019$ Institute of Advanced Engineering and Science. All rights reserved.

\section{Corresponding Author:}

Zainuddin Notanubun,

Primary Teacher Education,

Faculty of Teachers Training and Education, University of Pattimura,

Dr. Tamaela Street, Campus PGSD Ambon 97114, Indonesia.

Email: znotanubun1956@gmail.com

\section{INTRODUCTION}

The change of the centralized to the decentralized government system is marked by a clear division of authority between the central and regional governments. The division of power sharing including financial authority is contained in Law No. 22 of 1999, which has been revised into Law number 32 Year 2004. It affects merger of Maluku Province Education and Culture office with the regional office of Ministry of National Education of Maluku Province. The Education and Culture Office of Maluku Province before the merger was under the authority of the Regional Government (Governor). Meanwhile, the Regional Education Office of Maluku Province is under the authority of central government (centralized). After the merger it became the Office of Youth and Sports education under the authority of the Governor (decentralization).

The consequences of the merger of the two institutions, of course, some employees are happy, but some are worried because of the many structures that must be eliminated. The removal of a number of structures, of course, also affects the employees at the two institutions. This occurs because of the demands of autonomy, which implies that regional authorities are given a large role to regulate their territory.

In modern management systems, both private organizations and public organizations will always exist and are recognized for their legitimacy if they are able to adapt to changes and the dynamics of society. To achieve this, any formal organization often evaluates the performance of its organization's structure so as to properly issue its organization restructuring policies to suit the changing development paradigm and the dynamics that develop in the surrounding community. 
According to Shapo [1], Organization is units consisting of a number of people. We need to remember that with the presence of people, there is also disagreement between them or quarrels. Quarrels within a particular unit or organization can cause degradation of morale and productivity, the working atmosphere becomes worse. This condition can cause competent employees leaving the organization [2].

A well-planned of restructuring process will have a positive impact on the appropriateness of employees placement [3]. Appropriate employees placement is the placement of individuals within the organization unit of work in accordance with the expertise and educational background of the employees [4]. This is of course very influential on the performance of the employees in the units of the organization. Giving equal opportunities to all structures to perform its functions well in accordance with the description of duties that has been set will be very good influence on improving the performance of employees in the structure [5].

In carrying out reforms including exercising some of the authority it possesses, local governments need organization devices established on the basis of their characteristics and needs. Exercise the authority of the Regional Government, an organization is required. Strong organizational management affects the performance of the employees in an organization [6].

Decline in the performance of employees in an organization generally influenced by the pattern of placement of people who are not in accordance with their areas of expertise [7]. Persons with specialist skills are scarce and indispensable, but when placed in an environment or work that is inconsistent with their expertise the results obtained from the labor are in fact unprofitable. In addition to the accuracy of the arrangement of expertise by field, there is also a need for suitable placement of expertise by level [8].

The results of research by experts found that personality dimensions can be related to performance, and can be used as a tool to predict success in work [9-10]. It should be understood that individual factors and environmental factors form the behavior of employees and their effects on performance achievement [11-12]. A fact that employee work behavior is a very important problem.

Referring to some of the results of the research presented, it can be concluded that the institutional restructuring has some implications that is the decline in organizational climate as well as differences in employee behavior in the form of improvement, rejection of changes in the form of threats and withdrawal reinforced by the increasing influence of employee behavior on organizational climate which is getting stronger.

In addition, the formation of employee behavior as well as its impact on performance achievement is based on a fact that employee behavior is a very important problem. Restructuring the organization of regional office for the sake of employees performance has positive and significant results. This means that if the organization's restructuring policy is made and regulated properly it will have a positive effect on the performance of employees, which of course can improve the performance of the organization [13].

Restructuring of the institution of the organization in this research is related to humanity and the organization itself. The restructure of organization is not just a change or just follow the trends done by other people or parties. In fact, the restructure of the organization must be adjusted to the level of needs to be restructured, how to be restructured, and where the restructuring is intended. In other words, institutional restructuring in this research is institutional restructuring by changing the management structure as well as the function and role to improve the quality and service in Education Office of Maluku Province.

\section{RESEARCH METHOD}

This study uses survey method because the research is done on large and small population, but the data studied is the data from samples taken from the population, so that the relative events, distribution and relationships among variables are found [14]. The Population in this research were 276 employees from the office of Education, Youth and Sport Department of Maluku province with working period minimally five years. The sample of this study is the entire population (saturated sample) so that the sample of this study was 276 people. The reason for taking the employees who have worked minimally five years is because they experience directly before and after the restructuring in both organizations, namely employees from the education office, and the office of the Ministry of Education and Culture.

The variables in this study consist of one independent variable and one dependent variable, and two intervening variables. The independent variable is restructuring of organization $(\mathrm{X})$ and organizational performance $(\mathrm{Z})$ is dependent variable, and intervening variable is employee performance (Y1) and leadership effectiveness (Y2). Figure 1 shows a causal relationship model between the two research variables. 


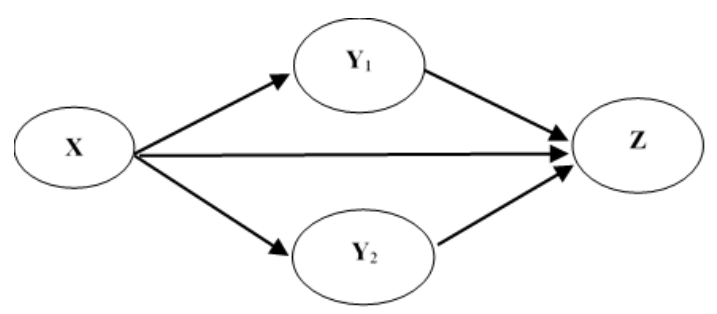

Figure 1. Research Design

Information

$\mathrm{X} \quad$ : Organization Restructuring

$\mathrm{Y}_{1} \quad$ : Employee performance

$\mathrm{Y}_{2} \quad: \quad$ Leadership effectiveness

Z : Organization's performance

Before the instrument is used to collect research data, it was first tested to test the validity and reliability, thus fulfilling the requirements used as a viable tool for the collection of research data. Table 1 shows the instruments used and the data collection techniques.

Table 1. Instrument and Technique of Data Collection

\begin{tabular}{cccc}
\hline Indicator & Target & Instrument & $\begin{array}{c}\text { Data Collection } \\
\text { Technique }\end{array}$ \\
\hline $\begin{array}{c}\text { Measuring organizational } \\
\text { restructuring, Employe } \\
\begin{array}{c}\text { Performance, Leadership } \\
\text { effectiveness }\end{array}\end{array}$ & Employee \& Leader & $\begin{array}{c}\text { Observation guidelines, interview } \\
\text { guides, and Performance Guidelines }\end{array}$ & $\begin{array}{c}\text { Observation, Interview, } \\
\text { and Research Form }\end{array}$ \\
$\begin{array}{c}\text { Organization } \\
\text { Performance }\end{array}$ & $\begin{array}{c}\text { The office of Education } \\
\text { Department Maluku } \\
\text { Province. }\end{array}$ & $\begin{array}{c}\text { Likert's Summated Ratings (LSR) and } \\
\text { Guidelines of Organization Performance }\end{array}$ & $\begin{array}{c}\text { Likert's Summated } \\
\text { Rating (LSR)\& } \\
\text { Assessment Forma }\end{array}$ \\
\hline
\end{tabular}

Data of research result is processed by using descriptive statistical analysis and inferential statistic analysis with path analysis method by using Lisrell program. Prior to hypothesis testing, analysis of the normality test of the distribution of error estimates regression equation was held, there was also significance test and linearity regression and multi co-linearity test free variable that is not hypothesized.

\section{RESULTS AND ANALYSIS}

To measure the restructuring of organization, the research distributed 23 statements to collect data about the restructuring that has been held for approximately 4 years at the Office of Education of Youth and Sports of Maluku Province. Figure 2 shows the percentage of restructuring.

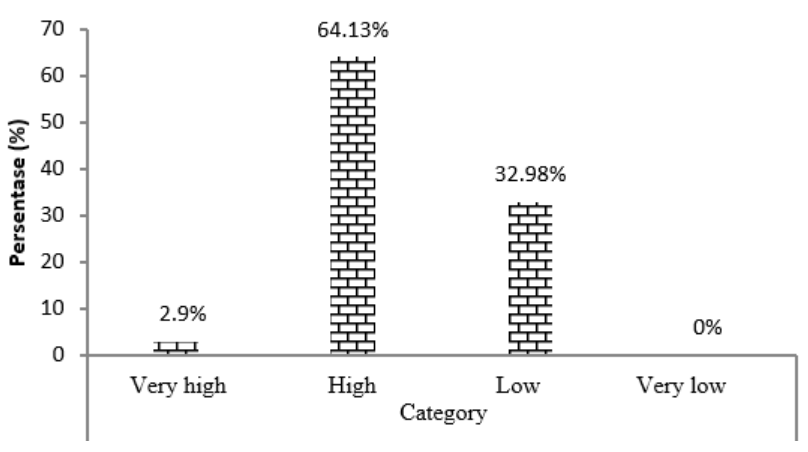

Figure 2. Percentage of organization restructuring 
Figure 2 shows that the restructure of the organization of the Office of Youth and Sport Education reaches very high category of only $2 \%$, high category gets $64.13 \%$ percentage, and low category $32.98 \%$, while very low category $0 \%$. These results indicate that the organization's recruitment of the Maluku Youth and Sports Education Office has performed well.

The organization's performance of the Maluku Youth and Sports Education Office, which relates to the implementation of the regional regulation (Perda) of Maluku number 2 of 2007 on restructuring, the researcher collected data through 26 items distributed to 276 respondents. Figure 3 shows the organization's performance presentation.

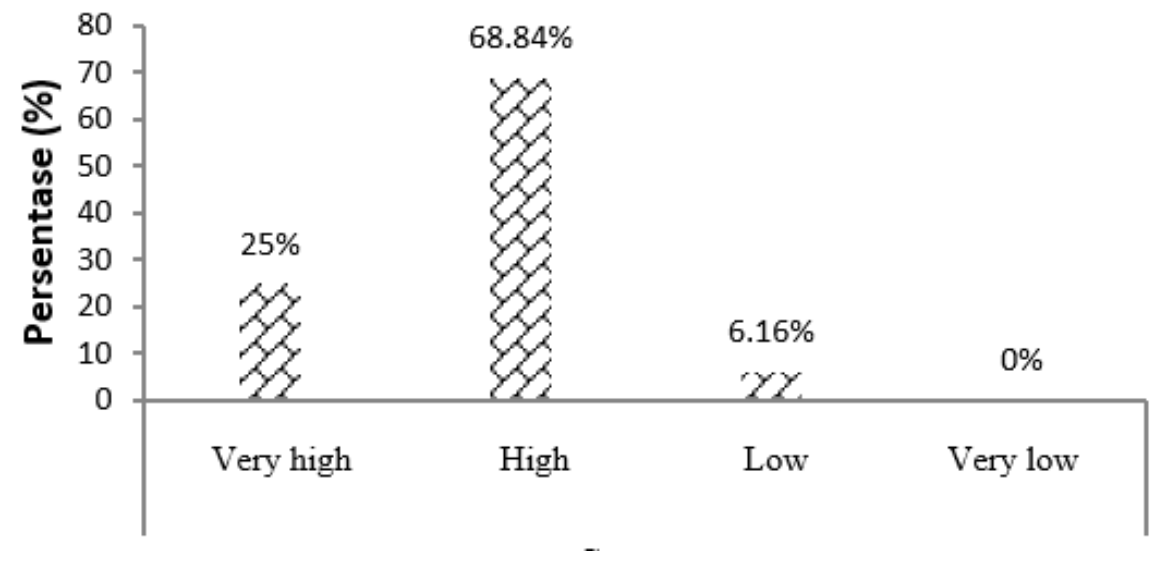

Figure 3. Percentage of Organization Performance

Associated with the organization's performance in the office of Education, Youth and Sport of Maluku Province as shown in Figure 3 that the performance of the organization obtained a very high assessment by respondents that is $25 \%$, respondents in the high category was $64.84 \%$, and $6.16 \%$ of respondents gave the assessment in the low category, and for very low category was $0 \%$. The achievement of this percentage indicates that the organization's performance in the Maluku Youth and Sports Education Office has good organizational performance.

To find out the influence restructuring of organization on the performance of the organization in which measured employee performance and leadership effectiveness, the data was analyzed using path analysis with AMOS for Windows in which the result can be seen in Figure 4.

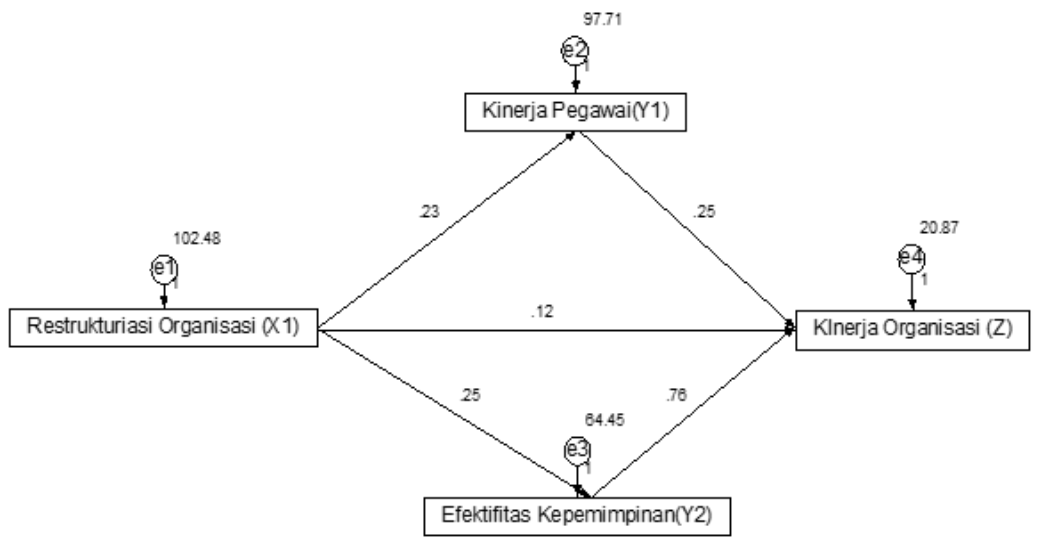

Figure 4. Path Analysis of the effect of organization reconstruction on organization performance

The results obtained from the path analysis in Figure 4 are further presented in Table 2, this is to facilitate the interpretation of the research data summarized on the path of decomposition coefficient. 


\begin{tabular}{cccc}
\multicolumn{2}{c}{ Table 2. Summary of Path Coefficient Decomposition } & \\
\hline Variables Influence & Direct & Indirect & Total \\
\hline $\mathrm{X} \mathrm{ke} \mathrm{Y}_{1}$ & 0.23 & 0.00 & 0.23 \\
$\mathrm{X} \mathrm{ke} \mathrm{Y}_{2}$ & 0.25 & 0.00 & 0.25 \\
$\mathrm{X} \mathrm{ke} \mathrm{Z}$ & 0.12 & 0.24 & 0.36 \\
$\mathrm{Y}_{1}$ ke Z & 0.24 & 0.00 & 0.24 \\
$\mathrm{Y}_{2}$ ke Z & 0.76 & 0.00 & 0.76 \\
\hline
\end{tabular}

Table 2 shows that the restructuring of organization $(\mathrm{X})$ is 0.25 , while the employee performance (Y1) is 0.233 . This result shows that the restructuring performed positively affects the employee performance, while the organizational restructuring variable (X) has no effect on the leadership effectiveness variable (Y2). From the results of the analysis it was clear that organizational restructuring variable $(\mathrm{X})$ is 0.25 , while the variable of leadership effectiveness is 0.76. Another result is the effect of organizational restructuring $(\mathrm{X})$ is 0.25 whereas organizational performance $(\mathrm{Z})$ is 0.12 this result shows that the restructuring carried out in the Office of Youth and Sports Education of Maluku province has a significant effect on organizational performance.

According to the result of causal analysis with path analysis it is known that employee performance (Y1) is 0,252 , leadership effectiveness (Y2) is 0,762, while organization's performance (Z) is 0,233 . These results indicate that employee performance and leadership effectiveness conducted at the Maluku provincial education office have a positive effect on organization's performance. Furthermore, to see the contribution of independent variables to the dependent variable, there was a further calculation. The results are presented in Table 3.

Table 3. Effective Contribution of Variable X, Variable Y to Variable Z

\begin{tabular}{lcll}
\hline The influence inter variable & Direct & Indirect & Total \\
\hline $\mathrm{X} \mathrm{ke} \mathrm{Z}$ & $(0.424)(0.12)=0.051$ & - & 0.051 \\
$\mathrm{Y}_{1} \mathrm{ke} \mathrm{Z}$ & $(0.363)(0.24)=0.092$ & - & 0.092 \\
$\mathrm{Y}_{2} \mathrm{ke} \mathrm{Z}$ & $(0.787)(0.72)=0.599$ & & 0.599 \\
$\mathrm{X} \mathrm{ke} \mathrm{Z}$ through $\mathrm{Y}_{1}$ and $\mathrm{Y}_{2}$ & & $(0.424)(0.121)+(0.303)(0.233)$ & \\
& & $+(0.232)(0.252)=0.242$ & 0.242 \\
\hline
\end{tabular}

Based on the calculation of effective contribution as shown in Table 3, it can be concluded that organization's performance can be explained or predicted by organization restructuring variable directly on organization's performance variable of $5.1 \%$. Variable performance of employees directly on organizational performance variable of $9.0 \%$, and variables of leadership effectiveness directly on the variable of organization's performance of $59.9 \%$, while the organization restructuring variable through the performance variable of employee and effectiveness of the leadership of $24.2 \%$. The total contribution of effective organization restructuring, employee performance, and effectiveness of leadership on the performance of the organization either directly or indirectly equal to $94.6 \%$ while the rest of $5.4 \%$ influenced by other factors not examined.

On the whole of the research result, it is identified that reconstruction gives influence to the performance of the organization either directly or indirectly through employee performance and leadership effectiveness. Restructuring undertaken not only limited to the existing system within the organization, but also concerns changes about the pattern or form of the organization. Restructuring the structure of an organization, including the Maluku Youth and Sports Education Office not only reorganized its structure, but the most important thing is to measure the effectiveness and efficiency of the structure so as to achieve optimal results.

The restructuring that has been implemented in the office of Education, Youth and Sport in Maluku Province encourages employees to improve their performance. In addition, to communicate the performance targets to all employees in order that they can achieve the target that has been set. In distributing of tasks, attention should be given to the competencies that each individual has in order that the task can be accomplished effectively.

The findings indicate that the restructuring carried out in the office of Education, Youth and Sport department of Maluku Province motivates employees to improve their performance. The performance is basically dependent on the performance of the individuals who are employees in this office. With the central role of the employees, there should be an effort to improve their performance in order to rise the performance of the office. It is important for local governments to manage the performance of employees, so that employees are able to give their best performance. 
Employee performance management is still largely untouched. This can be seen from the agency's reporting performance practices that are still limited to the disclosure of the achievements of the plans at the institutional level. At the individual level, however, new performance is measured based on attendance by using a performance appraisal list (DP3) assessment tool, even though the assessment tool has not been able to record the employee's overall performance. For that reason, a standard formulated by this office is required in the discipline of entry, or going home after work hours, how long the employee can complete the assignment, and the accuracy of completing the job, and the satisfaction of the job as well as the ability to communicate with colleagues, superiors, and the community that is served.

Based on the above explanation, it can be said that the performance of employee of Education, Youth and Sports department of Maluku province in carrying out all work done within a certain time duration. In addition, to accomplished the performance targets to all employees in order to achieve the target set. In the distribution of tasks, it is not only divided to employees but their competencies should be considered. This is intended to improved the office performance. Improved performance should use be measured using the right measuring tool, such as the job given to the employee to do whether it has been completed it in accordance with the specified duration or not? In addition, are the results of the work appropriate? If the employee completes the work according to the predetermined duration and, the result is satisfactory, it indicates that the employee's performance is getting better.

Associated with the effectiveness of leadership, the leaders should help individuals to collectively solve problems effectively. An important leadership function is to influence individuals to acknowledge or to recognize an important issue, not to deny it, to neglect the seriousness of the problem, or to provide fake repairs and diversions to reduce the pressure.

Effective leadership is a leader who is able to persist in carrying out his leadership consistently, albeit in a state of uncertainty. Even, he can also improve the professionalism of his employees in serving stakeholders effectively and efficiently, and can evolve with time changes [15-16].

Recognizing the central role of employees, the government is unlikely to achieve a high-performing institution without any effort to improve employees' performance. Therefore, it is very important for the Education, Youth and Sports department of Maluku province to be restructured optimally and supported by employee performance as well as to activate good managerial leadership so that there will an impact on improving organization performance.

\section{CONCLUSION}

Based on the findings that have been described in the results and discussion, it can be concluded that, the restructuring of the Education Office of Maluku Province has a significant effect on employee performance, 2) Restructuring of organization implemented at the Education Office of Maluku province has no significant effect on leadership effectiveness. Similarly, leadership effectiveness has no significant effect on organizational performance. This is because the Head of Education Office of Youth and Sports of Maluku province has never followed fit and proper test (competency test) because directly determined based on education level in position, and rank. In addition, the head of education office must have a wide network both vertically and horizontally, organization restructuring carried out at the Maluku Provincial Education has a significant effect on organization' performance. Restructuring of Organization implemented in Maluku province has led to a change in behavior. Changes in employee behavior in the office improve the work ethic / individual performance. The performance of individual employees in the Education office of Maluku province can improve organizational performance, employee performance and leadership effectiveness have a significant effect on organizational performance.

Based on the conclusions formulated, it can be given some suggestions, namely: to create a healthy and competitive work climate then, organizational restructuring is necessary to be implemented. Employees need to be moved around between sections in order to provide refreshment for employees to be creative, innovative in carrying out tasks carried, and can provide excellent service for people who need it. Employees also need to be motivated so that they can work optimally and there should be a system of monitoring to improve employee performance. It is expected that in assigning a new leader in Education office, there must be a fit and proper test (competency test).

\section{REFERENCES}

[1] K. Shapo, "Organizational communication and conflict management," Management, vol. 18, no. 1, pp. 103-118, 2013

[2] M. Fox, L. P. Tost, and K. A. W. Benzono, "The legacy motive: a catalyst for sustainable decision making in organizations," Business Ethics Quarterly, vol. 20, no. 2, pp. 153-185, 2010. 
[3] C. R. Prince, E. J. Hines, P. H. Chyou and D. J. Heegeman, " Finding the key to a better code: code team restructure to improve performance and outcomes," Clinical Medicine \& Research, vol. 12, no. 1-2, pp. 47-57, 2014.

[4] T. D. Shanafelt and J. H. Noseworthy," executive leadership and physician well-being: nine organizational strategies to promote engagement and reduce burnout," Mayo Clinic Proceedings, vol. 92, no. 1, pp. 129-146, 2017.

[5] P. O. Akadiri, E. A. Chinyio and P. O. Olomolaiye," Design of a sustainable building: a conceptual framework for implementing sustainability in the building sector," Buildings, vol. 2, pp. 126-152, 2012.

[6] S. M. Simons and K. N. Rowland, " Diversity and its impact on organizational performance: the influence of diversity constructions on expectations and outcomes," Journal of Technology Management \& Innovation, vol. 6, no. 3, pp. 172-183, 2011.

[7] J. Downe, R. Cowell and K. Morgan, "What determines ethical behavior in public organizations: is it rules and/or leadership?" Public Administration Review, vol. 76, no. 6, pp. 1-12, 2016.

[8] S, Beechler and I. A. Woodward, "The global "War for talent", " Journal of International Management, vol. 15, pp. 273-285, 2009.

[9] A. M. Suliman, A. A. AbdelRahmanand and A. Abdalla, "Personality traits and work performance in a duty-free industry, " International Journal of Commerce and Management, vol. 20, no. 1, pp. 64-82, 2010.

[10] B. Wille, F. D. Fruyt and M. Feys, "Big five traits and intrinsic success in the new career era: a 15-year longitudinal study on employability and work-family conflict," Applied Psychology, vol. 62, no. 1, pp. 1-33, 2012.

[11] Y. Tsai, "Relationship between organizational culture, leadership behavior and job satisfaction, " BMC Health Services Research, vol. 11, pp. 2-9, 2011.

[12] P. Paille, Y. Chen , O. Boiral and J. Jin, "The impact of human resource management on environmental performance: An employee-level study, " Journal of Business Ethics, vol. 121, no. 3, pp 451-466, 2014.

[13] D. McEwan, G. R. Ruissen, M. A. Eys, B. D. Zumbo and M. R. Beauchamp, "The effectiveness of teamwork training on teamwork behaviors and team performance: a systematic review and meta-analysis of controlled interventions, " Plos One, vol. 12, no. 1, pp. 1-23, 2017.

[14] Kreitner, Robert, dan Angelo Kinicki, Organizational behavior, New York: Addison-Wealey Publishing Campany, Inc, 2001.

[15] L. Agote, N. Aramburu and R. Lines, "Authentic leadership perception, trust in the leader, and followers' emotions in organizational change processes," The Journal of Applied Behavioral Science, vol. 52, no. 1, pp. 35-63, 2016.

[16] H. N. Tambingon, "The influence of principal leadership style and teacher work motivation on the performance of certified teachers at SMA Negeri Kotamobagu, North Sulawesi, Indonesia," Journal of Education and Learning (EduLearn), vol 12, no. 3, pp. 357-365, 2018

\section{BIOGRAPHIES OF AUTHORS}

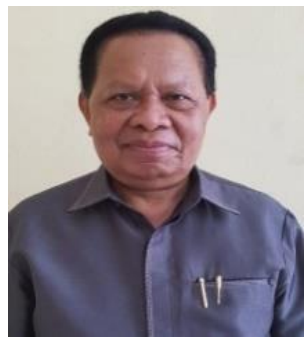

Zainuddin Notanubun is a Doctor of Public Administration

Lecturer at Primary Teacher Education, Faculty of Teachers Training and Education, Pattimura University, Ambon-Indonesia. Jalan Dr. Tamaela Kampus PGSD, AmbonMaluku, Indonesia.

Email: znotanubun1956@gmail.com

Interest research: Indonesian language education, teaching and learning model, primary education, educational design, education management and public administration.

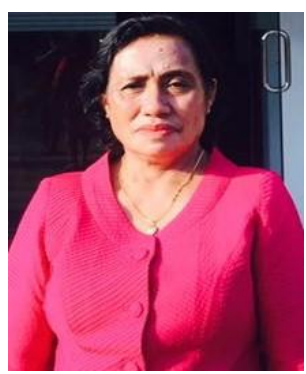

Ribka Lemi Ririhena is a Master in Indonesian Language Education

Lecturer at Primary Teacher Education, Faculty of Teachers Training and Education, Pattimura University, Ambon-Indonesia. Jalan Dr. Tamaela Kampus PGSD, AmbonMaluku, Indonesia.

Email: ribkaririhena@yahoo.com

Interest research: Indonesian language education, teaching and learning model, primary education, and educational design.

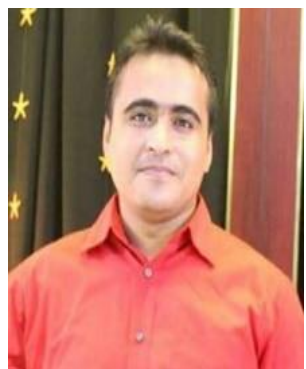

John Rafafy Batlolona is a Master of Physics Education.

Lecturer at Primary Teacher Education, Faculty of Teachers Training and Education, Pattimura University, Ambon-Indonesia. Jalan Dr. Tamaela Kampus PGSD, AmbonMaluku, Indonesia.

Email: johanbatlolona@gmail.com; johnrafafybatlolona@gmail.com

Interest research: physics education, science education, teaching and learning model, primary education. 